\title{
Reverse Mission and the Establishment of Re- deemed Christian Church of God (RCCG) in Canada
}

\section{Dele Jemirade ${ }^{1}$}

\section{Abstract}

This article examines the transplantation from Nigeria to Canada of the Redeemed Christian Church of God (RCCG). It argues that the concept of reverse mission, an increasingly popular view held by some scholars and church leaders that churches from Africa, South America and Asia are now re-evangelising the secular Western world, is but a rhetoric and a myth that does not describe the true nature of the church's activities in Canada. Statistics have shown that there is a decline in church attendance in the Western world including Canada. However, this research establishes that RCCG parishes in Canada are far from being successful with regards to their purported efforts to arrest this through a reverse mission. Instead of winning new souls for Christ among the secularised Canadians, the RCCG is only actively serving its predominantly black congregation. The two largest parishes of the church in Canada were used as a case study to determine that the reverse flow or reverse mission is not successful as some have wrongly assumed.

Key Words Reverse Mission, Reverse Flow, Re-evangelism, Pentecostalism, RCCG, Pentecostals, Church, Christianity, Globalisation, Redeemed Christian Church of God.

\section{Introduction}

The goal of this article is to examine the concept of the reverse mission of African Pentecostal denominations that are attempting to bring Christianity back to the Western world; that is to the people who introduced it to Africa in the first place. The article focuses on the reverse mission and the establishment of the Redeemed Christian Church of God in Canada with specific attention given to its two largest parishes: House of Praise and Covenant Chapel. This paper argues that the reverse mission is a myth that does not exist as far the establishment and success of Redeemed Christian Church of God in Canada and its two largest parishes are concerned. This is termed a myth because several pieces of evidence show that none of the programmes embarked upon by the parishes fits into the concept of reverse mission.

1 Dele Jemirade is a PhD Candidate in History Department, York University, Toronto Ontario, Canada, and can be contacted at delejemirade@yahoo.com or delej@yorku.ca. I thank Professor Femi Kolapo of History Department, University of Guelph, Ontario Canada for reading and making suggestions in all the different versions of the article. 
The notion of reverse mission is promoted by some Pentecostal churches, especially the RCCG. They preach to their congregation that the Western world is now secular and has abandoned Christianity, and it is their responsibility to re-evangelise them (Adogame 2006: 1). The RCCG and its leadership consider themselves at the forefront of reverse mission, based upon the number of branches they have established internationally and particularly in the Western world. The concept of the reverse mission was first encouraged in 1971 by Rev. John Gatu, the head of the Tanzanian Presbyterian Church, who, while addressing the Western Mission Circle, called for a moratorium on the activities of Western churches in Africa. Gatu was supported by many who believe that it is Europe and North America that need reevangelism, not Africa because Christianity is growing in Africa while it is declining in the Western world (Kalu 1980: 365-374).

The decline in church attendance in Europe and North America is articulated by the former Archbishop of Canterbury George Carey when he says "If the Church of England were a human being, the last rites would be administered at any moment". Carey describes the church "...as an elderly lady who mutters away to herself in a corner, ignored most of the time" (Jenkins 2007: 115). Cardinal Cormac Murphy0'Connor, Archbishop of Westminster, supports this argument when he says "Christianity, as a sort of backdrop to people's lives and moral decisions - and to the government, the social life of the country - has now almost been vanquished (Jenkins 2007: 115). The Catholic Cardinal Joachim Meisner of Cologne also supports this argument when he says "We have never had as much money as in the last 40 years, and we have never lost the substance of the faith as much as in the last 40 years...In the Cologne archdiocese there are 2.8 million Catholics, but in the last 30 years, we have lost 300,000. For every-one baptism, there are three funerals" (Jenkins 2007: 115).

Ronald Rolheiser argues that "The western world has been successful with regards to missionary activities in Africa, South America, Asia, and even the Arctic; however, in recent times it is unable to sustain it in its secularise countries and could not pass this message to its children" (Rolheiser 2006: 16). Reginald Bibby states that "In the last half of this century, active participation in organised religion in Canada has dropped fairly dramatically. At the end of the Second World War, some 60 percent of Canadians led by Roman Catholics in Quebec and elsewhere were attending services on a weekly basis. Today that figure stands at about 25 percent" (Bibby 2006: 55). This is the case with Christianity in Europe and North America, and the reason African Pentecostal churches like RCCG believe is it their responsibility to re-evangelise the western world.

This article is divided into three sections. The introduction discusses the aim of the article, the literature, the methodology, and the concept of reverse mission. The second section examines how the RCCG emerged; its metamorphosis from a 
small conservative prayer fellowship to a conservative Pentecostal church and into a liberalised charismatic, global Pentecostal church. This section looks closely at the church's two largest Canadian parishes, namely, House of Praise and Covenant Chapel, regarding the establishment, growth, the pattern of worship, liturgical, doctrinal differences, organisational structure, and hierarchy. The section examines the concept of a reverse mission and how it applies to the two RCCG parishes in Canada and analyses the senior pastors of these two parishes' styles of leadership. Section 3 analyses the impact of RCCG in Canada about the concept of reverse mission, the future of the church in the country and the conclusion.

\subsection{Literature Review}

RCCG has been the subject of several academic researchers in and outside Nigeria. Olufunke Adeboye examines the church's existence in the last fifty-three years, beginning with Josiah Akindayomi's conversion to Christianity. She traces the emergence and development of Pentecostalism in Nigeria and examines how RCCG emerged from the changes taking place in the Nigerian Christian community and the expansion of the church to many parts of the world (Adeboye 2007: 24-58). Adeboye also examines the first expansion of RCCG from Nigeria to Ghana and then the Republic of Benin. She concludes that the initial expansion process of RCCG to these two African countries was a failure and the church needs to redesign a better strategy in the future (Adeboye 2005: 465). Adeboye also addresses the establishment and growth of RCCG in North America from 1992 to 2005 as a fulfilment of the vision of its founder that the church will spread to all parts of the world (Adeboye 2008: 259-279).

Adogame examines the establishment, expansion and operations of RCCG in North America. He argues that the expansion of RCCG to North America is part of the overall globalisation vision of the mother church in Nigeria and addresses how the church reproduces ideas adopted from Nigeria and applies them in a global context (Adogame 2004: 24-50). Hunt examines the establishment of RCCG from its founding by Reverend Josiah Akindayomi up until 2002 and argues that the church's expansion is tied to its ability to address sociological and economic needs of the congregation in Africa as well as the Western world (Hunt 2002: 185-204). Asonzeh Ukah in his work examines the establishment of RCCG from its foundation years up to 2008 and argues about the growth of the of the church, which has impacted Christianity globally (Ukah 2008: 1-352).

Olowu examines the RCCG's global spread, especially in Europe and how the church grew from a tiny fellowship into one of the most powerful and influential Pentecostal churches in the world. Olowu argues that RCCG has acquired tremendous influence and has affected the communities in which the church operates despite the factors that militate against it, especially in places like Pakistan, Iran 
and Malaysia where there is a general hostility to any non-Islamic religion (Olowu 2009: 3-29). Burgess examines the civic and social activities of the RCCG in Britain, arguing the church's theology has influenced its civic, social and even political activities, all of which are mostly restricted to immigrant communities (Burgess 2009: 255-272). All these studies address various important aspects of RCCG, and this research is built on what they have accomplished.

According to the church website, there are one hundred, and forty-one (141) parishes of RCCG in Canada and more than half of them are in Ontario (RCCGNA: 2011). This article focuses on two of the largest parishes in Canada that is House of Praise in Toronto headed by Pastor Wale Akinsiku and Covenant Chapel also in Toronto headed by Pastor Tayo Ojajuji.

\subsection{Methodology}

Out of more than two hundred Senior Pastors and Assistant Pastors, two of the most senior pastors; Femi Olawale the Area Pastor of Canada and Tayo Ojajuni of Covenant Chapel, which is the first parish in Canada, were interviewed to obtain firsthand information about the church activities. To avoid some of the biases associated with oral sources, every effort was made to verify the information they provided on church websites and in publications. The participant interview lasted for about two weeks while more than twelve years was dedicated to gathering the rest of the information based on active church participation, which includes Sunday services, Friday services and the end of the year services. While conducting the participant interview and information gathering through observation of church activities, field notes were taken, which eventually became a very important source of the research. The participant interviews conducted were done in two ways. Pastor Femi Olawale was interviewed on the phone while Pastor Tayo Ojajuni was interviewed in person.

Although some of the evidence utilised here is based on my observation, participation in church activities and participant interviews, however, rather than be led by my personal views, I have subjected them to cross-examination of studies done by other scholars. In large part, my observation only serves to confirm these previous studies. This article will contribute to the development of the historiography of RCCG and the concept of the reverse mission by adding additional primary evidence in support of the argument that reverse mission as presently defined does not exist in RCCG Canada.

\subsection{Concept of Reverse Mission}

According to Ogbu Kalu, "[t]he influx of Christian leaders from the global south into the global north is described as the concept of reverse flow" (Kalu 2008: 271). A reverse flow, reverse mission or re-evangelism is the concept that African and other southern hemisphere-based churches are now preaching and reintroducing 
Christianity to Europeans and North Americans who were originally responsible for spreading the gospel to Africa and the rest of the south.

According to Adogame, "[t]he rationale for the reverse mission is often anchored on claims to the divine commission to spread the gospel; the perceived secularisation of the West; the abysmal fall in church attendance and dwindling membership; desecralisation of church buildings; liberalisation; and on issues around moral decadence" (Adogame 2006: 1). Gerrie Ter-Haar was one of the first to present an argument for the reverse mission when she examined the activities of African Christians in Europe and linked it to the rise of African Pentecostals. She argues that:

Europe will be dependent on Africa for renewed spiritual vitality. Due to secularisation, Western Europe has become a spiritual desert, a valley of dry bones, stripped of flesh and spirit. Europe is spiritually dead. It can come back to life only if somebody will prophesy and, following Ezekiel's example, tell these dry bones to listen to the word of God: a task African Christians have taken upon themselves. Hence a reverse mission has been set in motion (Ter-Haar 2009: 91).

However, Kalu argues that the reverse mission is not an invention of the Pentecostals and that it started in mainline orthodox churches, mainly the Lutheran World Foundation, in the nineteenth century. These churches anticipated that one day the churches in Africa, Asia and South America will become self-sufficient and will reinvigorate the churches in the western world. It was for exactly this purpose that Tanzanian Lutheran pastors were sponsored to serve in various Lutheran churches in Germany in 1980. This experiment was not successful, and the practice was later stopped by the church. The idea was modified by scholars to mean African, Asian and South American churches going to the Western world to reintroduce Christianity (Kalu 2008:271).

Although Kalu agrees with Ter Haar on the decline of Christianity in the Western world and that it is African Pentecostal churches that are sustaining it, he argues that with a few exceptions, the churches have mostly black congregations with few or no Caucasian members, which makes the reverse flow argument untenable (Kalu 2008: 283). Dapo Asaju argues that "the much talked about African Mission to Europe is not yet a success unless the Europeans who supposedly are being reevangelised are reached and converted. Operating Nigerian churches in western territories do not necessarily indicate missions in Diaspora" (Asaju 2008: 285). Adogame also supports this argument by stating that African Pentecostal churches must reach out and affect white European populations before they can lay claim to any success regarding the notion of the reverse mission (Adogame 2008: 260). 
Toyin Falola differs and argues that "The African churches in the west define their agenda in an ambitious manner: they not only want to minister to fellow immigrants, their main targets, but to 'remissionize' white people." He further argues that " $[\mathrm{t}]$ he idea of "reverse mission" is bold and creative, and already a phenomenal success in major western cities" (Falola 2005: 14).

Richard Burgess believes that African Pentecostal churches are very important in Britain where they are growing rapidly while church attendance at orthodox churches dwindles. He confirms the importance of RCCG parishes in London that are engaged in the local municipality by providing charity, relief materials and food for the elderly and the needy (Burgess 2009: 266). According to Burgess, RCCG in the UK assists new Nigerian immigrants, including access to schooling, housing and job opportunities, to help them integrate into society. Again, this cannot be considered a reverse mission because the beneficiaries are not the host community but the members of the respective parishes. While this is undoubtedly humanitarian behaviour, it cannot necessarily be considered a reverse mission because many non-Christian organisations also work to provide for the needy in the society (Burgess 2009: 266).

Philip Jenkins argues that "The era of Western Christianity has passed within our lifetimes, and the day of Southern Christianity is dawning. The fact of change itself is undeniable: it has happened and will continue to happen" (Jenkins 2007: 3). Jenkins further argues that "...immigrant Christians represent a potent cultural and religious force. Even if we accept the most pessimistic view of the faith of Christianity among Europe's old-stock white populations, these thriving new churches represent an exciting new planting, even potentially a kind of re-evangelisation" (Jenkins 2007: 118). However, Jenkins concludes that "It is hard to predict how the newer ethnic communities will continue to affect the religious life of the host societies" (Jenkins 2007: 116). Jenkins further questions the effort that has been made by the immigrant churches in the western world to integrate into the new cultures they find themselves (Jenkins 2007: 126).

Adogame, Burgess, Falola, Kalu, Ter Haar, Asaju and Jenkins all define the reverse mission, reverse flow, or re-evangelism as churches from Africa, Asia and South America preaching the Christian gospel to the Western world. However, the original Christian missions to these continents did more than preaching the gospel. They also built schools, clinics and dispensaries, and operated within a colonial system, which gave them power and influence. The missionaries who went to Africa, Asia and South America did not only preach to the people, but they changed their ways of life and affected their thinking.

The RCCG and its agents believe in the reverse mission, reverse flow or re-evangelism as strengthened by the vision of the founder of the Redeemed Christian Church of God (RCCG), Reverend Josiah Akindayomi, who prophesied the church would 
eventually spread to all parts of the world. Because of this vision, RCCG sees it as a divine responsibility to re-evangelise the Western world. To understand the vision of the founder of the RCCG and how it affects re-evangelising efforts in the western world, it is important to briefly retrace the history of the church from its early days.

\section{The Foundation of the Redeemed Christian Church of God (RCCG)}

According to Olufunke Adeboye, "[t]he growth of RCCG is discernable in three phases": 1952 to 1980 when the foundation was set, 1981 to 1989 when Pastor Enoch Adeboye restructured the church, and 1990 to the present, which represents the church's global expansion (Adeboye 2005: 445-446). RCCG was established in 1952 by Reverend Josiah Olufemi Akindayomi after he was excommunicated from the Eternal Sacred Order of Cherubim and Seraphim Movement, otherwise known as C\&S (Ukah 2008: 32). Reverend Akindayomi became a Christian when he joined the Anglican Church in 1927, which was represented by the Church Missionary Society (CMS) in Ondo, where he was baptised and named Josiah.

Because of his yearnings for knowledge, he enrolled as a pupil in the CMS School to acquire a Western education. Akindayomi became frustrated with the teachings of CMS and their doctrines, which condemned most aspects of Yoruba traditions. This frustration and spiritual yearning that CMS could not satisfy led him to drop out of school and join the Eternal Sacred Order of Cherubim and Seraphim Movement (C\&S) in 1931 in Ondo. From Ondo, he moved to Ile Ife in 1937 and then finally to Lagos in 1941 (Adeboye 2008: 261).

While in Lagos, Akindayomi worked at the C\&S Headquarters in Ebutte Metta under Prophet Abraham Onanuga, who was the spiritual head of the organisation, the Baba Aladura (Head of Prayers) of C\&S at that time. It was in Lagos that he was given the title of a prophet because of his zealotry in prayers, healings and heightened spirituality.

\subsection{Foundation by Reverend Akindayomi 1952 to 1980}

Akindayomi later formed a prayer group with twelve other church members in 1947 that he named Egbe Ogo Oluwa, which means "Glory of God Fellowship" (Agbedejobi 2000: 8-9).

In 1951, he renamed the fellowship the Ogo Oluwa Prayer Society (Agbedejobi 2000: 8-9). The prayer band became powerful and influential within the church, arousing the suspicion and jealousy of church leaders and some members. In 1952, the church leadership of C\&S later accused Akindayomi of forming a church within their church and expelled him together with his twelve disciples. This prayer group metamorphosed into a full-blown church known today as the Redeemed Christian Church of God (RCCG). 
Akindayomi first named the church Redeemed Church, then renamed it Redeemed Apostolic Church, then change it to Apostolic Faith Mission of South Africa (Nigeria Branch) and later Apostolic Faith Mission of West Africa (Ukah 2008: 45). The last three names reflected the church's initial association with the Apostolic Faith Mission Church. Finally, Akindayomi renamed the church Redeemed Christian Church of God (RCCG), a name which he claimed God gave him in a vision (Ukah 2008: 45). After parting with the C\&S, Akindayomi decided to renounce all the cultural practices and traditions associated with his old church. These include polygamy, and liturgical burning of candles, wearing long white robes, singing and drumming. He divorced his two junior wives and kept only the first one, making the church members follow his example (Ukah 2008: 45-46).

He assumed a new Bible-based focus for his church, like prayers, divine healing, speaking in tongues, bible studies, holiness, obedience, sacrifice, humility and faithfulness to God, again making the congregation follow suit (Olaleru 2007: 10). All these formed the basis of the doctrine of the new church which demanded restitution from the congregation. Akindayomi made the congregation to follow his examples because he was empowered by the constitution of the church to enact laws and runs the organisation as he saw fit including the power to excommunicate erring members. According to the church constitution, " $[\mathrm{t}]$ he founder of the mission, had unlimited powers to appoint or remove any officer as the Holy Spirit directed him" (Ukah 2008: 59).

Under Reverend Akindayomi, RCCG remained a conservative church largely populated by poor, lower-middle class and uneducated Nigerians from the Yoruba ethnic group. He frowned upon unnecessary acquisition and display of wealth by his congregation. He did not allow regular offerings to be taken and rather preferred that members donate money based on their free will as guided by the Holy Spirit. Services were conducted in Yoruba until English interpretations were introduced. At the time of his death on November 2, 1980, Akindayomi had succeeded in turning a small prayer group into a full-fledged church with forty branches mostly in southwestern Nigeria (Adeboye 2007: 37).

Before his death, Akindayomi predicted that his church would spread to all parts of the world. This prediction is today largely seen by church members as a covenant fulfilled by God, given the obvious spread of the church to most parts of the world as predicted by the founder. The prediction also serves as a charter cited by RCCG pastors regarding their responsibility to re-evangelise the Western world. Pastor Wale Akinsiku and Pastor Tayo 0jajuni of House of Praise and Covenant Chapel, respectively, don't use the phrases like "reverse mission or reverse flow" but use "re-evangelism" and emphasise that the church is given mandate by God to spread Christianity among the Western Caucasian populations that have abandoned Christianity. 


\subsection{Restructuring by Reverend Adeboye 1981 to 1989}

The second phase of RCCG's growth started when Pastor Enoch Adejare Adeboye became the head of the Church and took the post of the General Superintendent, which was later changed to General Overseer. Pastor Adeboye joined RCCG on July 29, 1973, after he was introduced to the church by his uncle, Reverend Chris Fajemirokun (Olaleru 2007: 157). Pastor Adeboye, who has a PhD in Applied Mathematics and was a Senior Lecturer at the University of Lagos, joined the church because of health-related problems afflicting his family that he was unable to solve with orthodox medicine. He, therefore, resolved to seek the intercession of a man of God (Reverend Akindayomi) based on his uncle's advice. Reverend Adeboye trained as a pastor in the church and was ordained in 1975 , beginning his rise to power.

Pastor Adeboye reorganised the church. A completely different person from his predecessor, he is educated, liberal and brought educated elites into the church. Reverend Akindayomi, meanwhile, had minimal education and with conservative ideas that could not attract the kind of crowd that would expand the church globally. In his attempt to modernise the church and to make it more attractive to the educated elites, the upper-middle class and the wealthy, Adeboye embarked on changes that were not favoured by the older members of the church, who believed he was deviating from the original doctrines of the founder (Adeboye 2007: 38).

As part of the plan to reorganise the church, Pastor Adeboye introduced the concept of "model parishes", which allows singing, hand clapping, musical instruments and performing services in English. The older churches were labelled classical parishes and allowed to continue to do services in the old traditions, especially in Yoruba with English interpretation (Ukah 2008: 110-117). When the classical and model parishes existing side by side did not yield the desired result; Pastor Adeboye decided to introduce what is now known as Unity Parishes as an attempt to integrate the elements of both types of parishes. Currently, RCCG conducts all church business in English without the option of interpretation in Yoruba, which was the church's original language of communication (Ukah 2008: 116-117).

Evangelism, which has always been a focus of the church, took a new turn under Pastor Adeboye, and the new emphasis was on reaching out to all segment of society, especially the rich and the elites, rather than only the poor and downtrodden. Under the old system, members were not asked to contribute financially but allowed to donate of their own free will, while the new system emphasises the importance of financial contributions; paying ten percent tithes and other free will financial contributions, which members claim bring blessings from God (Ukah 2008: 153-154).

Under Adeboye, there was still an emphasis on holiness, but prosperity gospel became paramount. This new trend was not only restricted to RCCG, as it was a new phase found throughout Nigerian Pentecostalism. According to Burgess, the 
prosperity gospel is the "teaching, which links faith and prayer with the expectation of material prosperity and success" (Burgess 2009: 285). Ayantayo defines it as "strong teaching about prosperity and the need for Christians to be prosperous while on earth" (Ayantayo 2010: 202). Pastor Enoch Adeboye himself, argues that "[t]he Lord has established a covenant of prosperity with the Redeemed Christian Church of God. So, if you are linked up with it, your breakthrough becomes automatic" (Adeboye 2006: 5). From the inception of the church until his death, Reverend Akindayomi discouraged unnecessary display of wealth by members. His extreme conservatism explains why he did not allow normal church offerings. However, after Pastor Adeboye took over and became the General Superintendent in 1981, the RCCG's view of prosperity changed.

Unlike Reverend Akindayomi, whose church was dominated by the uneducated, lower-middle class and the poor, Pastor Adeboye deliberately courted the educated, upper-middle class and the wealthy. Under Akindayomi, to be too rich and wealthy was frowned upon but under Adeboye to be poor is a curse, because poverty, according to him, is a curse put upon man by Satan and only God the Almighty through Jesus Christ, the saviour can remove the yoke of penury (Ukah 2008: 186).

When preaching, both Pastor 0jajuni of Covenant Chapel and Pastor Akinsiku of House of Praise emphasise the importance of breaking the yoke and chains of poverty and the importance of wealth and prosperity. This prosperity gospel is preached regularly into the ears of the members. RCCG believes that members must make a deliberate effort to acquire wealth. For RCCG, therefore, wealth is a sign of blessings from God while poverty is a curse from Satan (Ukah 2008: 184-186). Prosperity preaching is related to financial contributions to the church by individuals. The RCCG believes that when you give to God without a reservation, you will also receive abundant financial blessings in return; it is a two-way street, and the more you give, the more you get. The pastors of House of Praise and Covenant Chapel exhort the congregation to give plenty to receive more. Giving to God comes in the form of normal church offerings, tithes and voluntary donations and gifts to the church and its pastors. The church insists that the ten percent tithe of members' gross monthly salary or profit is compulsory and non-negotiable; it is a sin against God if one fails to pay it to the church (Ukah 2008: 184-186).

According to Hunt, " $\mathrm{t}]$ he distinctly African doctrinal component is discernible in the RCCG" (Hunt 2002: 192). Like many other Pentecostal churches in Nigeria, under pastor Adeboye, RCCG is characterised by its African elements such as loud prayers and singing, drumming and clapping, all of which are absent in orthodox Christianity. However, the leadership and congregation preferred Western styles of dressing and listen to Western styles of gospel music. This preference is because of Western education, exposure to Western culture and the influence of Pentecostal 
churches from Europe and North America. The new system also emphasises giving leadership positions to educated elites, most RCCG pastors today are university graduates, and it is rare that someone is ordained as a pastor without having a bachelor's degree or its equivalent (Olowu 2009: 13). From 1990s, Pastor Adeboye refocused the church and strives to expand the church to every part of the world in fulfillment of its founder's vision that " $[t]$ he church would spread to the ends of earth and would still be serving faithfully when the Lord returned to the earth in the second coming" (RCCG: 2011).

Adeboye eventually moved the headquarters of the church in 1982 from its original site in Lagos to its present site, Redemption Camp that measures about 10 square kilometers; (Ukah 2008:260), and is the venue of the monthly Holy Ghost Night that attracts an average of 500,000 people in a single night (RCCG: 2011).

\subsection{Global Expansion 1990 to the present}

After consolidating his power, Pastor Adeboye then began globalising the church. From the 1990s to date, it has successfully carried out a global expansion, and the church can now be found on the five continents. This global expansion was not accidental; rather, it was as the result of a deliberate effort by the church leadership led by Pastor Adeboye. Based on the vision and mission of the church articulated above, the church set out to establish numerous parishes in Nigeria, especially in the southwest and the Lagos area. The proliferation of parishes by the church, especially in areas where elites can be attracted and near universities and other institutions of higher learning, made the church to become more popular and acceptable among the populace, especially the elites. While many Pentecostal churches have emerged in Nigeria, however, Redeemed Christian Church of God (RCCG) is still the most popular among them.

According to Ruth Marshall, "Pentecostalism is more messianic than it is eschatological" (Marshall 2010: 206). She argues that the messianic expectation preaches by the Pentecostals is not the end of the world as it is understood, but part of the present time, something that is part of the present chronology and will happen before the end of the world itself or the apocalypse (Marshall 2010: 206). The RCCG and other Pentecostal messianic expectations are hinged on the fact that Christ is coming back to the world to defeat Satan and rule for one thousand years before the final apocalypse. This can be seen in the daily activities of RCCG and other Nigerian Pentecostals and the expectation that the coming of the Messiah or the eventual return of Christ is imminent. Pentecostals preach to their congregations to be prepared and be ready for the coming of Christ and to put all their hope in His Coming Kingdom. This is one of the reasons for the Pentecostal explosion in Nigeria; the message of hope of something good to come resonates with the poor 
and the rich, the illiterate and the educated (Marshall 2010: 206-207). The Pentecostal explosion in Nigeria led to the churches establishing branches in different parts of the world, particularly the Western world, led by RCCG.

In pursuance of its vision and mission, the church established its first parish outside Nigeria in Ghana in 1981 (Adeboye 2005: 456-460). The establishment of parishes in Ghana signalled the beginning of the global expansion and RCCG's spread throughout Africa, Europe, Asia, North America, South America, Australia, New Zealand and even some parts of the Middle East (RCCG: 2011). The expansion into the Western world signifies what RCCG and some of the Pentecostal Churches refer to as the re-evangelism of the Western world, which scholars have named reverse flow or reverse mission.

\subsection{RCCG in Canada}

The first RCCG parish in Canada emerged out of a fellowship started by Pastor Daniel Ishola in May 1995 after he arrives Toronto from Nigeria in search of employment opportunities. Ishola did not come to Canada to establish any RCCG parish, and he was not concerned with re-evangelising Canadians. He came as a Nigerian migrant looking for work in Toronto, and just like Pastor James Fadele who started the first parish in the United States; Ishola was a worker in RCCG in Nigeria and was encouraged by his Nigerian Pastor, Mr Ayinoluwa and his wife to start a fellowship when he arrived in Canada. With the help of Mrs Bisi Odukoya and Mrs Lee, he invited a few more friends and started a house fellowship that met every Wednesday at the Food Court of the Scarborough Town Centre (Ishola 2011: 24). Ishola kept in touch with the Ayinoluwas, who continued to encourage him despite the lack of an RCCG pastor to head the church. RCCG in Nigeria eventually sent Pastor Ayo Adeloye to come and inaugurate the church. In late 1995, the Covenant Chapel was inaugurated at the banquet hall of the Quality Inn Scarborough (Ishola 2011: 24).

Pastor Adeloye appointed Ishola as the church agent for Canada but could not make him the pastor because he was not ordained at that time. Pastor Adeloye went back to Nigeria with the promise of sending a pastor to lead the flock. While the young parish was struggling without a pastor, they were getting help from pastors from the USA who took turns flying to Toronto to conduct Sunday service for the congregation. Notable among them were Pastors Toye Ademola, Dave Okunade, Ajibike Akinkoye and James Fadele. These pastors had all started branches of RCCG in the United States (Ishola 2011: 24). The small fellowship continued until May 1996 when the General Overseer, Pastor Adeboye came to Toronto to dedicate the church. The dedication of the church was done at 1181 Finch Avenue West, the first venue of the new and first Canadian parish, Covenant Chapel. That same day, Pastor Adeboye ordained Ishola as a pastor and the head of the new parish (Ishola 2011: 25). 
Believing he had instructions from God to take over the Canadian capital, Ishola moved to Ottawa in 1997, and with the help of Ms Idowu, Adetokunbo Aluko, Abimbola Akinfenwa, Tope Oderinde and Mr Ayeire, he opened the second RCCG parish in Canada, calling it Overcomers Parish. According to him, all he wanted was to establish more parishes with the help of other Nigerians. Later that same year, Pastor Segun Arimoloye became the first pastor of the new parish, Pastor Bowo Olagbegi started the third parish, Throne of Grace, in Windsor, and Pastor Tokunbo Okunnu established the fourth parish, International Christian Centre, in Winnipeg (Ishola 2011: 25). In 2000, with the assistance of Mr Dapo Kolawole, Deacon Tunji Ajayi and Pastor Andrew Adeleke, Pastor Ishola established the fifth parish, House of Praise Mississauga. With the recommendation of Pastor Andrew Adeleke of Jesus House London UK, Pastor Wale Akinsiku was appointed the pastor of House of Praise Mississauga in 2000 (Ishola 2011: 25).

Eventually, Pastor Ishola was compelled to return to Nigeria due to immigration issues, and he handed over Covenant Chapel to Pastor Tayo Ojajuni in August 2000 (Ishola 2011: 25). In 2001, Pastor Demola Odushote established the sixth parish in Scarborough, initially known as the Triumphant Chapel though the name was later changed to Jesus House Scarborough. The seventh and eighth parishes were established on the same day in 2003, these are Kings Court Toronto and Jesus House Toronto. Beginning with a fellowship of three individuals, RCCG later established a Canadian parish in 1995 and now has one hundred and forty-one parishes in all the ten provinces of Canada.

According to Pastor Adeloye, who inaugurated the first parish, the success of RCCG's establishment in Canada is the realisation of its founder's vision and the covenant he made with God when the church was founded in 1952 that the church would reach all parts of the world (Ishola 2011: 25). Although this can be regarded as a justification of the vision of the founder, however, establishing parishes in Canada that are solely dedicated to serving predominantly Nigerian members is far from a reverse mission, reverse flow or re-evangelism.

Currently, there are one hundred and forty-one parishes in Canada, and they are divided into three provinces, headed by provincial pastors; twelve zones, each of which is managed by a zonal pastor. Administratively, Canada is an Area which is part of North America, under Pastor James Fadele, who is the Chairman Board of Coordinators RCCGNA. The three provincial pastors and twelve zonal pastors report to Fadele and the Canada Area Pastor in Ottawa in the name of Pastor Femi Olawale. Pastor Olawale reports to Pastor Fadele who is based in RCCGNA Headquarters in Dallas Texas. Pastor Fadele reports directly to the General Overseer in Nigeria. According to Pastor Olawale, the zonal pastors' report to him on Canadian issues and report to Pastor Fadele on issues about North America and that the RCCG in Canada has about twenty thousand five hundred members (Olawale 2011). 
According to Pastor Tayo Ojajuni, the current pastor of Covenant House, his parish has grown from a congregation of eighty people in 1999 to more than 2000 members, and it now holds two services every Sunday. He also says that more than ten parishes have come out of his parish, and it is the responsibilities of the mother parishes to produce new parishes and nurture them (Ojajuni 2011). According to Pastor Wale Akinsiku, the parish pastor of House of Praise Mississauga, his congregation has grown from twenty people to 3000 people, and it currently holds three services every Sunday (Akinsiku 2011).

\subsection{How did the doctrinal beliefs and practices of RCCG relate to the concept of reverse mission?}

RCCG is characterised by uniformity in doctrine, beliefs and liturgy among its thousands of parishes. These are spelt out on the church's website, (RCCG 2011), and based on observations made of Covenant Chapel and House of Praise; there are no deviations from what the international headquarters requires of its parishes. RCCG believes in the authority and supremacy of both the Old and New Testament as inspired words of God. This is followed by the belief in one God who is omnipresent, omniscient and omnipotent. They believe that Jesus Christ is the son of God, he is God, and he is the saviour and died for our sins. They believe in the Trinity and that God the Father; Jesus Christ the Son and the Holy Spirit make up the Trinity that every Christian must believe.

The major doctrinal belief of RCCG that relates to the concept of reverse mission is articulated in the vision and mission of the church, which states that " $\mathrm{t}]_{0} \mathrm{~h}$ have a member of RCCG in every family of all nations... we will plant churches within five minutes walking distance in every city and town of developing countries and within five minutes driving distance in every city and town of developed countries" (RCCG: 2011). This doctrinal belief is supported by the vision of the founder who claimed that God had shown him through a vision that the church will reach all parts of the world and will still be serving when the second coming of Jesus Christ occurs. RCCG is encouraged by this statement and belief to evangelise, re-evangelise and plant their church in as many parts of the world as possible.

Responses from the pastors that were interviewed and personal observations from attending the church for over twelve years reveals that both Covenant Chapel and House of Praise adhere to these doctrinal beliefs in their Sunday and weekly services. However, the two pastors of the churches, Pastor Tayo Ojajuni of Covenant House and Pastor Wale Akinsiku of House of Praise, bring their personalities to bear on the way these beliefs, doctrines, liturgies and dogmas are pursued. The pastoral programs of these two pastors, which are different from the stated church doctrines are guided by the latter and do not contradict each other. Pastor Akinsiku, 
a trained pharmacist, is a firebrand preacher and a motivational speaker while Pastor Ojajuni, a trained software engineer, is a gentle teacher and a philosopher. Their different characteristics and temperaments reflect the way their respective services are conducted, the way the administrations are organised and the general behaviour of the church workers. The two pastors are provincial pastors, meaning they have other parishes and zonal pastors under their supervision.

Although the RCCG's globalisation strategy articulated in the mission and vision of the church is deliberate and planned, Pastor Ishola, the man who is responsible for establishing the first, second and fifth RCCG parishes in Canada, did not migrate to Canada for that purpose. He migrated from Nigeria to Canada to seek better personal opportunities, but like Pastor Fadele who was the pioneering RCCG pastor in the US, Ishola was encouraged by the church leaders in Nigeria.

According to Ukah, migration plays a significant role in the expansion of RCCG all over the world. He argues that it was Nigerian migrant workers, mostly educated elites, who settled in different parts of the world that helped expand the church to its current size (Ukah 2005: 317). Adogame supports this argument and claims that most African churches were established in the Western world by migrant workers and students who started house fellowships that later led to the formation of churches that received the support and blessings from their headquarters in Africa (Adogame 2007: 438). Marshall also supports this argument in stating that most Pentecostal churches in Nigeria began as a small fellowship that later became big churches (Marshall 1993: 217).

Globalization might be a deliberate goal of RCCG, but its Canadian success came because of an individual who came for a different reason and was only encouraged once he was there. This encouragement is also a deliberate church policy that was clearly confirmed by S. T. Adetoye, the senior pastor of the RCCG National Headquarters in Nigeria who revealed to Ukah that "If you are a member of the RCCG and you decided to settle elsewhere as a result of migration or job transfer, you don't just settle in your new location, you must settle a church too. You start a fellowship that must become a church that is how the church has been growing" (Ukah 2005: 317). This is evident in both the Covenant Chapel and House of Praise, where the congregations are largely Nigerians and others from African countries but very few Caucasians.

\subsection{The Redeemed Christian Church of God (RCCG) Canada and Reverse Mission}

Similar to the studies carried out by Burgess of RCCG parishes in UK, my observations confirm that the leading RCCG parishes in Canada are essentially Nigerian churches operating in predominantly Caucasian communities with no participation from these communities, and the reverse mission, reverse flow or re-evangelism, a word preferred mostly used by RCCG pastors in Canada is non-existent. In my observation 
of both Pastor Ojajuni and Pastor Akinsiku of Covenant Chapel and House of Praise respectively, they never use the phrases "reversed mission or reversed flow" however they used words and phrases like "re-evangelism", "God ordained or anointed" the RCCG and its pastors to spread the gospel to every part of the world including Canada. Another common saying by the pastors is "The RCCG is on a mission to spread the gospel of Jesus Christ to all parts of the world, including people who had heard the word before and backslide and those that have never heard the Word before".

Although both Covenant Chapel and House of Praise donate money to charities annually, this does not constitute reverse mission. Since 2010, through church announcements, House of Praise annually donates more than $\$ 40,000$ to different charities within the Greater Toronto Area, and Covenant Chapel also donates more than $\$ 20,000$ annually, but this cannot be considered a reverse mission because many non-religious organisations do the same. RCCG is not the only exception; most African Pentecostal churches operating in Diaspora are only serving their migrant communities. In most cases, the white host communities in Western nations are not involved in the churches.

The only African church in Diaspora that has a $98 \%$ white majority in the congregation is the Embassy of the Blessed Kingdom of God founded in Kiev, Ukraine in 1992, by Pastor Sunday Adelaja (Jenkins 2007: 247). The majority of the more than 25,000-member congregation are Ukrainians and Russians (God Embassy: 2011). This, however, is the only example of the success of the reverse mission, reverse flow or re-evangelism. In my analysis of data of church activities, fliers and posted programs, nothing seems to show a deliberate policy by RCCG parishes in Canada to evangelise white people and make them members of their church. Their target is the Nigerian community and in some cases the African community at large. My analysis of data from church activities, fliers and posted programs shows that the target of the two parishes studied, is predominantly its African members.

Both Pastors Akinshiku and Ojajuni believe that re-evangelising Canada is part of their God-given responsibilities and the success of their parishes signifies the success of reconverting Canadians to Christianity. However, the evidence of ethnic, national and racial provenance of the churches is contrary to this claim on the success of re-evangelising Canadians. For RCCG to attract non-Africans or whites into their fold, they must deemphasise the Afrocentric nature of their church and explore avenues that can attract non-Nigerians and non-Africans.

\section{The contributions of RCCG to communities in Canada}

RCCG is one of the fastest-growing churches in the world; it is found on every continent and even in countries like Malaysia, Pakistan and Iran that are traditionally hostile to Christianity (Olowu 2009: 5). There is no doubt that RCCG is a big 
church by any standard of measurement and its influence is global. The leader of the church, Pastor Enoch Adejare Adeboye, is regarded as one of the most influential people in the world. In December 2008, Newsweek Magazine recognised Pastor Adeboye as one of the fifty most influential people in the world. In an interview with Lisa Miller, the Newsweek Senior Editor, Pastor Adeboye confirms that RCCG has roughly 14,000 parishes in more than 110 countries and more than five million members all over the world (Newsweek Magazine 2008).

Since the establishment of RCCG Canada in 1995, the church has steadily grown and now boasts of one hundred and forty-one parishes across the country. However, based on my observations, RCCG Canada is an immigrant church and has not broken the barrier to become a truly Canadian church or a church that represents the general Canadian population. A Canadian church in this sense would be a church that is populated by the different racial configurations in Canada.

The situation is the same with the UK parishes studied by Burgess that are dominated by Nigerians of Yoruba origin. Because it is an immigrant church, it has succeeded in creating a central point for Nigerians to come together to worship and socialise. It fills the vacuum created by the distance from Nigeria for most of its members who are new migrants in the country, and it gives value to the identities they cherish. The church provides an avenue for its African members, especially $\mathrm{Ni}$ gerians, to name their children, dedicate their children and conduct marriage ceremonies within the ambit of what was possible in Nigeria (Adogame 2004: 38-43).

Based on my observations, the church satisfies sociological and psychological aspects of African life that are otherwise missing in Canada. The church also serves as a focal point for community services. New immigrants can solicit help from other members of the church who have been in the country for a longer period on essentials such as employment, housing, immigration matters, and education. One can draw a parallel between what is happening in Canada and what is happening in the United Kingdom.

RCCG parishes in the UK provide social, religious support and networks to their congregations (Burgess 2009: 256). Just like RCCG parishes in the UK; the RCCG parishes in Canada serve as a cushion and provide a soft landing for new immigrants. Far from penetrating the host communities regarding the reverse mission, RCCG parishes in the UK according to Burgess, are Nigerian churches operating and catering to Nigerian immigrants. Most of the members of the congregation are black Yoruba Nigerians, and there are very few whites and non-Africans among the congregation (Burgess 2009: 263).

Besides the fact that RCCG in Canada is an immigrant church, it is also largely a Yoruba church. From my observations of the people who attend Covenant Chapel and House of Praise, most are Yoruba from the southwest region of Nigeria where 
the church has its roots. In fact, based on the information provided by the RCCGNA website, the Area Pastor, the three Provincial Pastors and almost all the Zonal Pastors in Canada are Yoruba and more than ninety-five percent of the pastors in Canada are of Yoruba origin (RCCGNA: 2011). I have occasionally seen a Caucasian in the congregation, but otherwise, all the members are black. It is difficult for the RCCGNA to remove its ethnic identity from its profile as the church is currently constituted in Canada; it is simply a successful ethnic-based immigrant church.

Based on my observations, the church in Canada is not converting new Christians in the host community, does not target non-Africans and is far from success as far as the reverse mission is concerned. Most members of the congregation were members in Nigeria before they moved to Canada, and RCCG in Canada is largely providing a home for its immigrant congregation from Nigeria rather than saving new souls for Christ among the non-African population (Asaju 2008:285).

Based on my observations, the RCCG currently provides an avenue for human development. On a regular basis, the parishes organise seminars, conferences and lectures where experts in various fields are invited to share their success stories and advise others on how to follow the path of success. Through these events, the church can provide an avenue for networking and business links among its members and non-members who attend these programs.

Through African Missions, which is an RCCG charity program in developing countries, RCCG Canada has helped communities, women and children in Kenya with money, food, drugs and clothing. African Missions Canada has drilled several bore-holes in Kenyan villages to provide clean drinking water for the people. These activities are particularly concentrated in the villages of Turkana and Obaga in the Rift Valley Region. African Missions Canada also opened a women's skills development centre in Nairobi that specialises in training former prostitutes for semiskilled labour (Africa Missions: 2011).

The African Missions program also conducts a fundraiser called Toonies for Africa in which parishes encourage its members and non-members to donate two dollars or more to help alleviate water problems in African communities. The program also sponsors medical missions, training and mentoring, educating and equipping young girls and boys, and supporting missionaries proclaiming the gospel in remote areas of Kenya (Africa Missions: 2011). Looking at all these activities, one can conclude that most of RCCG Canada's charity programs target immigrant members and Africans who truly need the assistance.

Despite the fact, that the RCCG is largely a Yoruba immigrant church, it has succeeded in keeping the flame of Christianity alive in Canada. Church attendance has greatly declined among the white majority in Canada, and only Pentecostals churches like RCCG have succeeded in maintaining a large congregation. The contribu- 
tions of RCCG and other Pentecostals to the renewal of Christianity in Canada cannot be overemphasised. All the Orthodox churches, namely, the Catholic Church, the United Church, the Anglican Church, the Methodists, the Lutherans, the Presbyterians and the Baptists, have lost most of their congregation. The churches are mostly empty or half empty and once-full pews are now being turned into museum pieces (Canadian Christianity 2011).

Jenkins writes that "In Canada as in Europe, immigrant groups have slowed the general decline in churchgoing". Moreover, "The effects of immigration can be seen across the denominational spectrum. People of African and Caribbean stock have revived Catholic communities in the metropolitan countries" (Jenkins 2007: 114-115). It is obvious that new interests in Christianity and Christian faith in Canada has been rekindled and kept alive by the efforts of immigrant churches like RCCG. Jenkins states that a 2005 study in Canada of actual church membership against notional adherence discover that between 1961 and 2001, the Anglican Church in Canada lost 53\% of its members; the United Church lost 39\%, and attendance in the Catholic Church declined from $48 \%$ to 29\% between 1988 and 1998 (Jenkins 2007: 115). All the evidence available here simply attest to the fact that there is a general decline in church attendance and general interest in Christianity by Canadians compare to $40-50$ years ago.

\section{Conclusion}

This article examined the RCCG's transplantation from Nigeria to Canada, argued that the concept of reverse mission is rhetoric and does not describe the true picture of RCCG's activities in Canada. Adogame rightly describes the reverse mission concept as rhetoric (Adogame 2006:1). It will remain so unless the African Pentecostal churches reconsider their approach towards evangelism in the Western world. This article also analyses the activities of the main actors and key players that were responsible for the growth and sustenance of RCCG in Canada as well as the activities of the church in the present. The process of transplantation to Canada was not deliberate, though it forms part of a deliberate plan orchestrated by church leaders in Nigeria.

Ishola was not sent to Canada to establish RCCG, but the church encourages its members to start new fellowships, and he received this encouragement even when he did not have a permanent residence in Canada. Although RCCG Canada remains an immigrant church that is largely dominated by Yoruba people from the southwest region of Nigeria, it has so far failed to integrate non-Africans into its congregation. However, it has successfully catered to the social, civic and spiritual needs of migrant workers seeking a religious and ethnic identity in Canada.

The RCCG has a future, and it has the chance to become a real Canadian church if deliberate efforts are made to bring non-Nigerians and non-Africans to its con- 
gregations. Because the church is continually growing, it has the chance to become a dominant church in Canada. RCCG is not the sole Pentecostal church in Canada with roots in Nigeria. With Christ Embassy and Winners Chapel, as well as other smaller denominations from Nigeria, they represent a very strong and potent force representing the Christian religious interest of immigrant Nigerians and Africans. Each of these independent African Pentecostal churches presents an avenue for possible academic research in the future.

\section{References}

Adeboye, E. A. 2006. "Levels of break-through" in Open heavens: A daily Guide to close fellowship with God, 4. Cape Town: Struik Christian Books Ltd.

Adeboye, 0.A. 2005. Transnational Pentecostalism in Africa: The Redeemed Christian Church of God, Nigeria in Entreprises Religieuses Transnationales en Afrique de l'Ouest, edited by L. Fourchard; A. Mary and R. Otayek. Paris: Karthala: 439-465.

Adeboye, 0.A. 2007. Arrowhead of Nigerian Pentecostalism: The Redeemed Christian Church of God, 1952-2005. Pneuma, 29 (1): 24-58.

Adeboye, 0.A. 2008. Running with the Prophecy: The Redeemed Christian Church of God in North America, 1992-2005. Missionalia, 36 (2) \& (3): 259 - 279.

Adogame, A. U. 2006. Reverse Mission: Europe a prodigal Continent? Unpublished Study Material.

Adogame, A. U. 2008. Who do they think they are? Mental Images and the unfolding of an African Diaspora in Germany in Christianity in Africa and the African Diaspora: The Appropriation of a Scattered Heritage, edited by A. Adogame; R. Gerloff and K. Hock. New York: Continuum International: 248-264.

Adogame, A. U. 2010. The Rhetoric of Reverse Mission: African Christianity and the Changing Dynamics of Religious Expansion in Europe. Unpublished Study Material.

Adogame, A. U. 2007. African Christian Communities in Diaspora in African Christianity: An African Story, edited by 0. U. Kalu. Trenton, New Jersey: Africa World Press: 438.

Adogame A. U. 2004. Contesting the ambivalences of modernity in a global context: The Redeemed Christian Church of God, North America. Studies in World Christianity, 10 (1): 24-50.

Agbedejobi, F. (ed.) 2002. The Redeemed Christian Church of God: 50 Years of Phenomenal Growth and Spiritual Development. Lagos: Dove Publications.

Asaju, D. 2008. Colonial Politicization of Religion: Residual Effects on the Ministry of African Led Churches in Britain in Christianity in Africa and the African Diaspora: The Appropriation of a Scattered Heritage, edited by A. Adogame; R. Gerloff and K. Hock. New York: Continuum International: 279-292.

Ayantayo, J. 2010. Prosperity Gospel and Social Morality in Creativity and Change in Nigerian Christianity, edited by D. Ogungbile; A. Akinade, Akintunde. Lagos: Malthouse Press Limited: 201-216. 
Bibby, R. 2006. On boundaries, gates, and circulating saints: a longitudinal look at loyalty and loss in Religion and Canadian Society: Traditions, Transitions, and Innovations, edited by L. G. Beaman. Toronto: Canadian Scholars: 35 .

Burgess, R. 2009. African Pentecostal Spirituality and Civic Engagement: The Case of the Redeemed Christian Church of God in Britain. Belief and Values, 30 (3): 255-272.

Falola, T. 2005. The Iyalorisa and the Pastor, Introduction in Christianity and Social Change in Africa: Essays in Honor of J.D.Y. Peel, edited by T. Falola. Durham: Carolina Academic Press: 14.

Hunt, S. 2002. A Church for All Nations: The Redeemed Christian Church of God, Pneuma, 24 (2): 185-204.

Ishola, D. June 2011. Celebration: RCCGNA Canada's First Annual Convention Publication.

Interview June 2011 with Pastor Tayo 0jajuni; the parish pastor of RCCG Covenant Chapel and Provincial Pastor for Province 1 in Canada

Interview June 2011 with Pastor Femi Olawale; the parish Pastor of RCCG Overcomes Chapel and Area Pastor for Canada

Jenkins, P. 2007. The Next Christendom: The coming of Global Christianity. Oxford: 0xford University Press.

Jenkins, P. 2007. Godless Europe' International Bulletin of Missionary Research, 31 (3): 115-120.

Kalu, O.U. 1980. Church, Mission and Moratorium in The History of Christianity in West Africa edited by 0.U. Kalu. London and New York: Longman: 365-374.

Kalu, O.U. 2008. African Pentecostalism: An Introduction. Oxford: Oxford University Press, 2008.

Marshall, R. 2010. The Sovereignty of Miracles: Pentecostal Political Theology in Nigeria 1. Constellations, 17 (2): 197-223).

Marshall, R. 1993. Power in the name of Jesus: Social Transformation and Pentecostalism in Western Nigeria in Legitimacy and State in Twentieth-Century Africa; essays in Honor of A.H.M. Kirk-Green, edited by T. Ranger and 0. Vaughan. Basingtolle, England: Macmillan: 213-246.

Miller, L. December 19th, 2008. Newsweek Magazine. http://www.newsweek.com/newsweek-50-e-adeboye-83039. (June 5th, 2011).

Olaleru, 0. 2007. The Seed in the Ground: The story of the founding of Redeemed Christian Church of God. Lagos: Father of Lights Publishers.

Olowu, D. 2009. Faith-Based Organisations and Development: The Case of an African Indigenous Church's Global Reach-Redeemed Christian Church of God in Contribution to the Religion and Development Volume, edited by G. Ter Haar. Institute of Social Studies, The Hague, Netherlands: 3-29.

Rolheiser, R. 2006. Secularity and the gospel: being missionaries to our children, New York: Crossroad.

Sunday Sermon January 2011 by Pastor Wale Akinsiku; the parish pastor of RCCG House of Praise and Provincial Pastor for Province 2 in Canada

Ter Haar, G. 2009. How God became African: African Spirituality and Western Secular Thought, Philadelphia: University of Pennsylvania Press. 
Redeemed Christian Church of God (RCCG), http://www.rccg.org (June 4th, 2011).

Redeemed Christian Church of God North America (RCCGNA), http://www.rccgna.org (June 4 th, 2011).

African Missions Canada, http:// www.africanmissions.ca (June 4th, 2011).

Canadian Christianity, http://www.canadianchristianity.com (June 4th, 2011).

Embassy of the Blessed Kingdom of God for All Nations, http://www.godembassy.com (June 4th, 2011).

Ukah, A. 2005. Mobilities, Migration, and Multiplication: The Expansion of the Religious Field of the Redeemed Christian Church of God, Nigeria in Religion in the Context of African Migration, edited by A. U. Adogame; C. Weisskoppel. Bayreuth, Germany: Bayreuth African Studies Series: 317-341.

Ukah, A. 2008. A New Paradigm of Pentecostal Power: A Study of Redeemed Christian Church of God in Nigeria. Trenton, New Jersey: Africa World Press. 